\title{
Örgütsel Adalet ve Örgütsel Bağlılık İlişkisinde Örgütsel Özdeşleşmenin Rolü:Üniversite Çalışanları Üzerine Bir Örnek
}

\author{
DOI: 10.26466/opus.621947
}

\author{
Fetullah Battal $^{*}$ \\ * Dr. Arş. Gör., Bayburt Üniversitesi, İktisadi ve İdari Bilimler Fakültesi, Bayburt / Türkiye \\ E-Posta: $\underline{\text { fbattal@bayburt.edu.tr }}$ \\ ORCID: $\underline{0000-0002-2895-0193}$
}

\begin{abstract}
$\ddot{O} z$
Bu çalışmanın amacı örgütsel adalet, örgütsel bağhllık düzeyi ve örgütsel özdeşleşme algıları arasındaki ilişkileri ortaya koymaktır. Araştırmada kullanılan veriler, bir devlet üniversitesinde çalışan 206 personelden yüz yüze anket aracılığı ile toplanmıştır. Toplanan veriler orijinal SPSS 22.0 ve AMOS 25.0 paket programı yardımıyla analiz edilmiştir. Çalışmanın sonucunda ulaşılan en genel bulgu çalışanların algıladığı örgütsel adalet ile örgütsel bağlllık ve örgütsel özdeşleşmenin olumlu ve anlamlı yönde ilişkili olmasıdır. Ayrıca kavramların alt boyutlarının ilişkisine bakıldığında örgütsel adalet ile süreklilik bağgllı̆̆g arasında anlamlı bir ilişkinin olmadığı görülürken aynı zamanda örgütsel adaletin alt boyutlarından olan duygusal bağlllık ile süreklilik bağhllı̆̆ı arasında da anlamlı bir ilişki olmadı̆̆ gözlenmiştir. Bunun yanında çalışanların örgütsel adalet algıları ile örgütsel bağlllık davranışı arasındaki ilişkide örgütsel özdeşleşmenin kısmi aracılık rolünün bulunduğu tespit edilmiştir. Son olarak bu çalışmada çalışanların ulusal kültürü ele alınmış ve konu ile ilgili teorik varsayımlar yapılmıştır. Bu yönüyle bakıldı̆̆ında Türkiye'nin dişi bir toplum olduğu ve duygularıyla hareket eden bireylerin ă̆ırlıkta olduğu daha önceden yapılan çalışmalarda ortaya koyulmuştur. Böylece sonuçların ulusal kültür ile uyum içerisinde olduğunu söylemek mümkündür.
\end{abstract}

Anahtar Kelimeler: Örgütsel Adalet, Örgütsel Bă̆lllık, Örgütsel Özdeşleşme 


\title{
The Relationship Between Organizational Justice and Organizational Commitment: The Role of Organizational Identification
}

\begin{abstract}
The aim of this study is to reveal the relationships between organizational justice, organizational commitment level and perceptions of organizational identification. The data used in the research were collected through 206 face-to-face questionnaires working in a public university. The collected data were analyzed with the help of the original SPSS 22.0 and AMOS 25.0 package program. The most common finding reached at the end of the study is that the organizational justice perceived by the employees is positively and significantly associated with organizational commitment and organizational identification. In addition, when the relationship between the sub-dimensions of the concepts is analyzed, it is observed that there is no significant relationship between organizational justice and continuity commitment, and at the same time, it is observed that there is no significant relationship between the emotional commitment, which is a sub-dimension of organizational justice, and continuity commitment. In addition, it has been determined that organizational identification has a partial mediating role in the relationship between organizational justice perceptions and organizational commitment behavior.

Finally, in this study, the national culture of the employees is discussed and theoretical assumptions are made on the subject. Given this aspect that Turkey is a society in which the female and the feeling of moving subjects with a heavy-ness it has been revealed in previous studies. Thus, it is possible to say that the results are in harmony with the national culture.
\end{abstract}

Keywords: Organizational Justice, Organizational Commitment, Organizational Identification 


\section{Giriş}

Günümüzde hızla gelişen ve değişen teknoloji ile birlikte örgütler ve örgüt içinde çalışan bireyler de bu değişime ayak uydurmak zorunda kalmıştır. Bu dönüşüm çalışanlar ve yöneticiler için çeşitli fırsat ve tehditleride ortaya ç1karmaktadır. Belirli amaçlara ulaşmak niyetiyle biraraya gelen bireylerden oluşan örgütler hedeflerine ulaşabilmek için en değerli kaynak olan insan faktörünü verimli bir şekilde kullanmak zorundadır. Bu yönüyle bireyin hedefleri ile örgütün hedefleri arasında bir dengenin kurulabilmesi, işgücü devir hızlarının azaltılması ve verimliliğin optimal düzeylere çıkarılması için en önemli faktör çalışanların örgütsel bağlılık düzeyleridir. Çalışanların örgütsel bağlılık davranışları arttıkça örgüt ile bütünleşmeleri ve uyumlu hale gelmeleri kolaylaşır böylece örgüt ile özdeşleşmeleri de sağlanabilir. Aynı zamanda örgütsel bağlllık hisseden bireyler daha gönüllü ve fedakar tutumlar sergiler. Ancak bu davranışların sağlanabilmesi için çalışanların öncelikle adaletli bir işyerinde çalıştıklarına inanmaları gerekmektedir.

Literatür incelendiğinde örgütsel adalet, örgütsel bağlllık ve örgütsel özdeşleşme ile ilgili birçok çalışmanın yapıldığı görülmektedir. Örneğin literatür incelendiğinde çalışanların örgütsel adalet algılarının yüksek olmasının örgütsel bağlllık düzeylerini olumlu yönde etkileyeceği kabul edilmektedir (Türköz, Polat ve Coşar, 2013, s.285; Bal, 2014, s.75). Ayrıca örgütsel adalet algisını örgütsel özdeşleşme algisı üzerinde de etkisi olduğu ileri sürülmektedir (Ateş, 2015, s.75; Cüce, Güney ve Tayfur, 2013,s.1). Bu çalışmalara ek olarak örgütsel bağlllık ile örgütsel özdeşleşme arasındaki bağlantılara da literatürde rastlanmak mümkündür. (Van Knippenberg ve Sleebos, 2006, s.571; Demirel, Derin ve Çakınberk, 2011).

Ancak bu çalışmada özgün olarak üniversite çalışanlarının örgütsel adalet algılarının örgütsel bağlılık algıları üzerindeki etkisinde örgütsel özdeşleşmenin aracı rolünün bulunup bulunmadığı ilk defa ortaya konulmuştur. Dolayısıyla da çalışmanın sonucunda elde edilen veriler ülkemizde bu ilişkiyi ortaya koymak adına önemli bir boşluğu giderebilir ve literatüre bu yönüyle katkı sağlayabilir. Araştırma bir devlet üniversitesinde akademik ve idari kadrolar da çalışan bireyler üzerinde yapılmıştır. 


\section{Kuramsal Açıklamalar}

\section{Örgütsel Adalet}

Genel olarak adalet terimi " doğruluk " ya da "dürüstlük " anlamına gelmektedir (Colquitt ve diğerleri, 2001, s.425). Yapılan bu tanımdan hareketle; adalet din, ahlak, eşitlik ve hukuk ile bağlantılı olabilir (Usmani ve Jamal, 2013, s.351).

Organizasyonun en stratejik unsuru olan insan kaynağına, yönetimler tarafından özel olarak dikkat edilmiştir. Bilim adamları adalet ve yönetimi insanın temel ve içsel ihtiyaçlarından biri olduğunu savunmaktadır. Adalet ile ilgili görüşlerin tarih boyunca gelişmesi insan toplumlarını geliştirmek için uygun bir zemin oluşturmuştur (Lapidot ve diğerleri, 2007, s.16).

Araştırmacilar adalet kavramının örgütsel gerekliliklerin yerine getirilmesinde temel oluşturduğunu ifade etmişlerdir. Adalet terimiyle ilgili literatür tarandığında, işyerlerinde adaletin rolünü tanımlamak için "örgütsel adalet" olarak adlandırılan bir terim kullanılmaktadır (Özdemir, 2013, s.102). Örgütsel adalet terimi ilk olarak 1987 yılında Greenberg tarafından ele alınmıştır (Usmani ve Jamal, 2013,s.351). Greenberg (1987) örgütsel adaleti, çalışanların örgütsel politikalara, uygulamalara ve kararlara ilişkin adalet algılamaları ve bu algıların çalışanların davranışları üzerindeki etkisini açıklamaya yönelik girişimler olarak tanımlamıştır (Greenberg, 1990, s.399).

Ayrıca örgütsel adalet, iş yerinde adalet araştırması olarak da tanımlanabilir. Byrne ve Cropanzano, 2001, s.3) Aynı zamanda örgütsel adalet, eğitimciler tarafından 1970'lerde sosyal adalet boyutlarından biri olarak geliştirilmiştir. Artık örgütsel adalet örgütsel davranışlarla ilgili yeni konulardan biri olmuştur (Choudhary ve Kumar, 2011). Greenberg (1990) Örgütsel adalet üzerine araştırmaların geçmiş, şimdiki ve gelecekteki durumlarını değerlendiren bir makalede, örgütsel adalet araştırmasının birçok örgütsel davranış sonucu değişkenini potansiyel olarak açılayabileceğini öne sürmüştür (Greenberg, 1990, s.399).

Örgütsel adalet, 21. yüzyıl örgütlerine yardımcı olabilecek kilit değişkenler arasındadır(Yuan Wang ve Zamantili Nayir, 2009, s.66). Örgütsel adalet önemlidir çünkü adil muamele daha iyi sosyal etkileşimlere ve genel örgütsel etkinliğe yol açmaktadır. Örgütsel adalet çok boyutlu bir kavram olmasına 
rağmen, temel olarak "bireylerin çalıştıkları kurumlarda adaletle ilgili alg1ları" olarak ele alınmaktadır (Coetzee, 2004). Örgütsel adalet, çalışanların adil muamelesi ile ilgilidir (Randeree, 2008, s.57). Ayrıca örgütsel adalet, işyerinde doğrudan ilişkili olan adalet rolünü tanımlamak içinde kullanılan bir terimdir. Bu yönüyle örgütsel adalet, çalışanların işlerinde adil bir şekilde muamele görüp görmediklerini ve bu tespitlerin iş ile ilgili diğer değişkenleri nasıl etkilediğini belirleme biçimleriyle de ilgilidir. Özünde, örgütsel adaletin değerini destekleyen araştırmacıların inancı, eğer çalışanlar adil bir şekilde muamele gördüklerine inanırsa, çalışmalarıyla, çalışma çıtılarıyla ve denetçileriyle ilgili olumlu tutumlar sergileme eğiliminde olacaklardır (Moorman, 1991, s.845).

Çalışanlar örgütsel adalet algılarını rastgele örgütsel olayların bir sonucu olan genel izlenimler, liderler ve iş arkadaşları gibi belirli "örgütsel bileşenlere" dayalı kişisel değerlendirmeler yoluyla kurarlar (Hollensbe ve diğerleri, 2008, s.1099). Dolayısıyla da örgütsel adalet, çalışanlar için önemli bir konudur ve bir bireyin iş yerinde adalet algısı olarak tanımlanabilir (Cropanzano ve diğerleri, 2001, s.164).

Örgütsel adalet sadece örgütsel performansı değil, büyük ölçüde, bir çalışanın ekonomik refahını da belirlemektedir. Böylece örgütsel adalet, işveren ve çalışanlar arasındaki ilişkiyi uyumlaştırmaya yönelik pozitif bir etki yaratabilir. Bunun tam tersi olarak çalışanlara adaletsiz bir şekilde davranmak, çalışanlar arasında yönetime yönelik olumsuz tutumlara (örneğin, talimatlara uymayı reddetme, alt standart iş performansı, şirket kural ve yönetmeliklerini kasttlı olarak ihlal etme vb.) neden olabilir. Bu nedenle bazı araştırmacılar tarafından işyerinde adalet konusunu anlamak için çeşitli çalışmalar yapılmıştır (Yean, 2016, s.798).

“Örgütsel adaletin" yapısı genellikle, dağıtım adaleti, prosedür (usul) adaleti ve etkileşimsel adalet olan üç özel bileşenle ilgilidir (Colquitt ve diğerleri, 2002, s.83).Illk olarak kabul edilen adalet türü dağıtım adaletidir. Dağıtım adaleti, çalışanın işyerindeki katkılarından dolayı aldığı ödülün adaletli bir şekilde elde edildiğini düşünmesidir (Greenberg, 1990, s.399). İkinci tür olan prosedür (usul) adaleti, ödüllerin dağıtımı ile ilgili karar almada kullanılan usullerin ve araçların hakkaniyetini ifade etmektedir (Folger ve Konovsky, 1989, s.115). Etkileşimsel adalet ise, çalışanların bir kurumdaki karar alıcılardan aldıkları kişilerarası muamele adaleti hakkındaki algılarını ifade etmektedir (Akram ve diğ.2017, s.134).Ayrica Cohen-Charash ve Specter'in (2001) 
yaptıkları araştırmada, üç örgütsel adalet boyutunun varlığını desteklemiştirler (Cohen, Charash ve Spector, 2001, s.278).

\section{Örgütsel Bă̆lılık}

Örgütsel bağlllık, bir bireyin kendisini örgütsel bir kişi olarak gördüğü dereceyi ifade eder ve bir bireyi organizasyona bağlayan psikolojik bir durum olarak tanımlanabilir (Meyer ve Herscovitch, 2001,s. 299). Ayrıca örgütsel bağlılık, bir bireyin belirli bir organizasyonla özdeşleşmesi ve bu organizasyona dahil olmasının göreceli gücü olarak da tanımlanabilmektedir. Porter ve ark.(1974) tarafindan tanımlanan örgütsel bağlllı̆̆ı üç ana bileşeni olduğu ileri sürülmektedir. Bu bileşenler: 1-Kuruluşun amaç ve değerlerine güçlü bir inanç ve kabul; 2-Kurum adına önemli çaba gösterme isteği; 3-Örgüt üyeliğini sürdürmek için güçlü bir arzu olarak sıralanabilir (Porter ve diğ., 1974, s. 603).

Örgütsel bağlılık, bir çalışan ile çalıştı̆̆ 1 organizasyon arasındaki bağı ifade ettiğine (Lambert ve diğerleri, 2013, s.480; Mowday ve diğerleri, 2013) göre çalışanların organizasyonda kalma veya organizasyondan ayrılma kararı almaları örgütsel bağlılık kavramının bir prensibini oluşturmaktadır (Meyer ve diğerleri, 1993, s.538). Bu prensipten hareketle örgütsel bağlllık, bir çalışanın organizasyon üyeliğini sürdürmek isteyip istemediğine karar vermek için kullanılabilir (Allen ve Mayer, 1996, s. 252). Örgüt üyelerinin örgütsel bağlılıkları azalırsa, çalışma tutkusu ve katılımlarının azalması muhtemel$\operatorname{dir}$ (Wu ve Chen, 2018, s.75). Örneğin, çalışanlar çalıştıkları organizasyon tarafından olumlu muamele görürse, organizasyona psikolojik olarak bağlanma olasılıkları yükselmektedir. Buna karşılık, çalıştıkları organizasyon tarafından kötü muamele görmeleri ya da haksız davranışlara maruz kaldıklarını düşünmeleri organizasyondan çekilme olasılıklarını daha da yükseltmektedir (Meyer ve Allen, 1997).

Meyer ve Allen'e (1991) göre, örgütsel bağlllığın ayırt edilmesi gereken üç farklı bileşeni vardır. Bu bileşenler duygusal bağlılık, devamlı bağlılık ve normatif bağlılık olarak adlandırılmıştır. Duygusal bağlılık, bir çalışan ile çalıştığı organizasyon arasındaki duygusal bağı tanımlar (Meyer ve Allen, 1991, s.61). Böylelikle kendi istemiyle ortaya çıkan organizasyon üyeliğinden çok zevk almaktadır (Allen ve Meyer, 1990, s.1; McShane ve Glinow, 2013). De- 
vamlı bağlılık, bir çalışanın algılanan maliyetten dolayı organizasyona bağlanmasını ve organizasyondan ayrılması durumunda acı çekebileceğini ifade etmektedir (Meyer ve Allen, 1991, s. 61). Normatif bağlllık ise, bir çalışanın belirli bir kuruma (örneğin ahlaki veya etik nedenlerden dolayı) karşı yükümlülük hissini yansitmaktadır (Spanuth ve Wald, 2017, s.129).

\section{Örgütsel Özdeşleşme}

Örgütsel birleşmelerin, devralmaların/devretmelerin ve yeniden yapılanmaların örgüt çalışanlarının bağlllıklarına yönelik tehditler oluşturması günlük örgütsel yaşamın bir parçası haline geldiğinden, örgütle belirli bir özdeşleşme seviyesi ortaya çıkarabilme yeteneği hem kuruluşların hem de üyelerinin refahı için giderek daha önemli hale gelmiştir. İyi bir örgütsel özdeşleşme duygusu çalışanların yabancılaşmasını önleyebileceği gibi genel iş tatmini duyguları içinde önemli bir ön koşul olmaktadır. Ayrıca, bir kuruluşla özdeşleşen üyelerin kuruluşta kalması ve kuruluş adına daha fazla çaba harcaması beklenmektedir (Dutton ve diğ., 1994, s.239).

Ashforth ve Mael, örgütsel özdeşleşmenin belirli bir sosyal kimlik biçimi olduğunu ve bir bireyin bir örgütle özdeşleştiği ölçüde, örgütün bireye bir kimlik duygusu sağladığını öne sürmektedirler. Bu nedenle örgütsel özdeşleşme tıpkı sosyal kimlik kavramında tutumlar ve davranışlar için temel oluşturduğu gibi, örgütsel tutumlar ve davranışlar içinde bir temel oluşturmaktadır. Ayrıca örgütsel özdeşleşme örgütsel işlevsellik üzerinde faydalı etkilerin temelini oluşturmaktadır (Dutton ve diğ.1994, s.239; Mael ve Ashforth, 1992, s.103).

Sosyal kimlik, bir bireyin bir grup sinıflamasına ait olma algısıdır. Birey, kendisini grubun gerçek veya sembolik bir üyesi olarak algılar (örneğin :'Ben bir erkeğim'; 'Yerel futbol takımının bir hayranıyım'). Birey sosyal kimlik aracllığıyla, kendisini grubun kaderiyle psikolojik olarak iç içe geçmiş, ortak bir kaderi paylaşmak, başarılarını ve başarısızlıklarını deneyimlemek olarak algılar (Tolman, 1943, s.141). Özdeşleşme, bireyin kendi gücünün ötesindeki başarılarda açkça yer almasına izin verir (Katz ve Kahn, 1978, s.528). Bu bakış açısına göre örgütsel özdeşleşme, bireyin kendisini belli bir organizasyona üye olarak tanımladığı bir sosyal kimliklendirme şeklidir (Mael ve Ashforth, 1992, s.103). 
Örgütsel özdeşleşme “tecrübelerimizi anlamamızı, düşüncelerimizi organize etmemizi, kararlar almamızı ve kendimizi demirlememizi" sağlayan önemli bir kavram olduğu için bilim insanları sıklıkla bu kavramı araştırmaktadırlar (Cheney, 1983, s.342). Ashforth ve Mael 1989 yılında yaptıkları çalışmada örgütsel özdeşleşmeyi, "bir üyenin kendisini, örgütü tanımladığına inandığı özelliklerle tanımladığı derece" olarak tanımlamıştırlar ( Ashforth ve Mael, 1989, s.20). Bir çalışanın örgüt ile özdeşleşme derecesi, algılanan benzerliğe ve organizasyonla paylaşılan kadere ve örgütsel üyeliğin olumlu benlik anlayışına ne ölçüde katkıda bulunabileceğine bağlıdır (Dutton ve diğ., 1994, s. 239; Mael ve Ashforth, 1992, s.103). Bir çalışan, kuruluşla ne kadar çok özdeşleşirse, kuruluşun pozitif çıktıları da çalışanların aidiyet duyguları da bu yönde artacaktır (Van Knippenberg ve Sleebos, 2006, s.571).

Örgütsel özdeşleşme, üyelerin örgütün tanımlayıcı özelliklerini kendileri için tanımlayıcı özellikler olarak benimsemeleri durumunda ortaya çıan bir psikolojik bağlanma biçimidir (Dutton ve diğ., 1994, s. 239). Ayrıca örgütsel özdeşleşme, bir organizasyonla algılanan bir birliktelik ve organizasyonun başarı ve başarısızlık deneyimini kendisininki olarak tanımlamaktır (Mael ve Ashforth, 1992, s.103) Aynı zamanda örgütsel özdeşleşme, bir örgüte aidiyet olma ya da o örgütle birlik olma algısıdır (Ashforth ve Mael, 1989, s.20). Örgütle güçlü bir şekilde özdeşleşmek, bireyin örgütsel üye olarak kendini hissetmesini sağlar. Çalışanlar iş yerleri ile güçlü bir şekilde özdeşleştiğinde, çalışanların organizasyona bağlı kalma duyguları organizasyonun hayatta kalmasına bağlıdır. Bu nedenle, çalışanların sadece bireysel çıkarlarından ziyade tüm organizasyonun yararına olacak şekilde muhtemel görevlere odaklanması gerekmektedir (Dutton ve diğerleri, 1994, s.239).

Cheney (1982) örgütsel özdeşleşmeyle ilgili yaptığı kapsamlı literatür incelemesinde bireylerin yaşadığı örgütsel özdeşleşmenin benzerlik, aidiyet ve üyelik duygularıyla tanımlandığı sonucuna varmıştır (Cheney,1982 Akt. Bullis ve Bach, 1989, s.273) Dutton ve Diğ., (1994), Cheney (1982)' nin bu sonucundan hareketle örgütsel özdeşleşme duygusunun, üyelerin organizasyona fayda sağlama, itaat, bağllıık, sadakat ve katılım gibi davranışlarla organizasyona daha sık ve daha fazla katkıda bulunacaklarını iddia etmişlerdir (Dutton ve diğ., 1994, s.239-263). 


\section{Araştırmanın Hipotezleri ve Modeli}

\section{Örgütsel Adaletin Örgütsel Özdeşleşmeye Etkisi}

Adalet kavramı, bireylere kendi gruplarında saygı duyulan üyeler olduklarını ve grup üyeliğinden gurur duyabileceklerini göstermektedir. Ayrıca grup üyeleri bu saygı ve gurur duyguları ile bağlantısı sayesinde, grupla daha fazla özdeşleşebilecektir. Bu nedenle grup üyelerinin örgütsel adalet algıları örgütsel özdeşleşme algıları ile pozitif olarak ilişkilidir (Tyler ve Blader, 2003, s. 349). Örgütsel adalet algıları yüksek olan ve benzer işlerde çalışan aile işletmesi çalışanlarının örgütsel özdeşleşme algılarında artmış olması beklenmektedir. Çünkü birçok aile işletmesinde çalışan bireyler aile fertlerinden oluştuğu için, aile üyesi olmayan çalışanlar, özellikle paylaşılan aile kimliğine sahip olmadıkları için örgüt içindeki önemlerini ya da değerlerini anlamak için örgütsel özdeşleşme duygularına güvenmektedirler (Carmon ve diğerleri, 2010, s.210). Olkkonen ve Lipponen (2006) yaptıkları çalışmada aile işletmelerinin usul ve dağıtım adalet algılarının ciro niyetleri ile ilişkisinin örgütsel özdeşleşme algılarına aracılık ettiğini bulmuşlardır. Örgütsel adaletin kişilerarası bilgilendirici etkisi örgütsel özdeşleşme ve bağlılık algılarıyla doğrudan bağlantılı olmamasına rağmen, bu tür adalet biçimleri aile işletmesinin başarısı için kritik öneme sahiptir. Çünkü aile işletmeleri kişiler arası bilgi adaletini dikkatlice uygulayarak ve geliştirerek çalışanların özdeşleşme derecelerini artırabilir. Ayrıca, bir çalışanın özdeşleşme algı algılayışı organizasyondaki diğer çalışanlarla ne kadar benzer koşullarda çalıştıklarına bağlıdır (Olkkonen ve Lipponen, 2006, s. 202).Bu verilerden yola çıkarak aşağıda ki hipotez ortaya konulmuştur:

H1: Örgütsel adalet, örgütsel özdeşleşmeyi olumlu yönde ve anlamlı bir şekilde etkilemektedir.

\section{Örgütsel Özdeşleşmenin Örgütsel Bağlılık Üzerindeki Etkisi}

1970'lerde Porter ve diğerleri (Porter ve diğ., 1974, s.358, Akt. Riketta, 2005, s.358; Mowday ve diğ., 1979, s.224) örgütsel özdeşleşmeyi tutumsal örgütsel bağlılığın bir bileşeni olarak tanımlamaktadırlar. O zamandan beri, bazı araş- 
tırmacılar örgütsel özdeşleşme ve tutumsal örgütsel bağlllık terimlerini eş anlamlı olarak ele almışlardır (Griffin ve diğ., 1986, Akt. Riketta, 2005, s.358; Mathieu ve Zajac, 1990, s.171).Literatüre bakıldığında, tutumsal örgütsel bağlılık ile örgütsel özdeşleşme arasında açk bir örtüşme olduğu gözlemlenmektedir. Özellikle de özdeşleşmenin açıç̧a tutumsal örgütsel bağlılığın tanımlarına dahil edildiği görülmüştür (Riketta, 2005, s. 358). Bu bağlamda bir kuruluşa bağlllık için temel nedenlerden biri kuruluşla özdeşleşmektir (Becker, 1992, s. 232). Ellemers ve diğ. (1997) yaptıkları çalışmada organizasyon ile güçlü bir şekilde özdeşleşen kişilerin organizasyona bağl1lık hissetme olasılıklarının daha yüksek olduğunu keşfetmiştirler. Bu nedenle bir çalışan bir kuruluşla özdeşleşmeye başlarsa, o zaman kuruluşa daha fazla kendini adanmış hissetmeye başlayacaktır (Ellemers ve diğ., 1997, s.617). Sonuç olarak bakıldığında örgütsel bağllıkla örgütsel özdeşleşme arasında bilimsel çalışmalara konu olarak derecede ilişki olduğu göze çarpmaktadır. Bu bulgulara dayanarak aşağıdaki hipotez geliştirilmiştir.

H2: Örgütsel özdeşleşme, örgütsel bağl1lığı olumlu yönde anlamlı bir şekilde etkilemektedir.

\section{Örgütsel Adaletin Bağhlık Üzerindeki Etkisi}

Örgütsel adalet, örgütsel uygulamaların oluşturduğu bir olgudur ve organizasyona yönelik tutumlara katkı sağlayan bir değişkendir. Örgütsel adalet ile örgütsel bağllık arasındaki ilişki derecesi nedeniyle araştırmacılar bu kavramlarla ilgilenmektedir. Örgütsel adalet ile örgütsel bağlllık arasındaki ilişkiyi araştırarak aralarındaki ilişkiyi destekleyen birçok çalışma vardır (Hopkins ve Weathington, 2006, s.477; Martin ve Bennett, 1996, s.84; McFarlin ve Sweeney,1999, s.626; Orpen, 1994; Yazıcioğlu ve Topaloğlu, 2009).

Araştırmacilar örgütsel adalet ve örgütsel bağlllık algısının örgütsel sonuçların önemli belirleyicileri olduğunu öne sürmüşlerdir (Alexander ve Ruderman, 1987, s.177; Folger ve Konovsky, 1989, s.115; Greenberg, 1987, s.9; Mc Farlin ve Sweeney, 1992, s.626). Birçok çalışma örgütsel adalet ile örgütsel bağlılık arasında pozitif bir ilişki olduğunu göstermiştir. Örneğin, Patrick (2012) yaptığı çalışmasında, organizasyonların bilgi teknolojisi bölümünde çalışan 225 katılımcı örgütsel adaletleri ile örgütsel bağlılıkları arasında pozitif ilişki olduğunu göstermiştir (Patrick, 2012). 
Organizasyonel usuller organizasyonun kaynaklarını tahsis etme şeklini temsil etmektedir. Bu nedenle usul adaletinin örgütsel bağlılık gibi organizasyona karşı bilişsel, duyuşsal ve davranışsal tepkilerle ilişkili olduğu tahmin edilmektedir. Organizasyon yönetimi tarafından alınan bir kararın haksız olduğu çalışanlarca algılandığında, çalışanların tepkilerini tüm organizasyona yönlendirileceği tahmin edilmektedir (Yöney, 2010). Bu bağlamda Lind ve Tyler (1988)yaptı̆̆ çalışmada usul adaletinin örgütsel bağlılık üzerinde güçlü ve olumlu bir etkisini öngörmektedir (Folger ve Konovsky, 1989, s.115). Sweeney ve McFarlin (1993) adalet dağıtımının ücret memnuniyeti gibi kişisel seviye değerlendirmelerini etkilediğini, prosedürel (usul) adaletin örgütsel bağlılık gibi örgütsel seviye değerlendirmelerini etkilediğini tespit etmiştir (Sweeney ve McFarlin, 1993, s.23). Ayrıca eski bir araştırma olan (Greenberg, 1990)' da dağıtım adaletinin örgütsel bağlılık üzerinde önemli bir etkisi olduğunu ortaya koymuştur (Greenberg, 1990, s.561). Martin ve Bennett (1996),'de yine örgütsel adaletin örgütsel bağlılıkla pozitif ilişkili olduğunu gözlemlemiştir (Martin ve Bennett, 1996,s.84). Buna ek olarak Sweeney ve McFarlin (1992), usul adaletinin dağıtım adaletine kıyasla örgütsel bağlılıkla daha fazla ilişkili olduğunu öne sürmüştür (McFarlin ve Sweeney, 1992, s.626). Buna göre aşağıdaki gibi hipotez geliştirilmiştir.

H3:Örgütsel adalet, örgütsel bağlılı̆̆ı olumlu yönde anlamlı bir şekilde etkilemektedir.

\section{Örgütsel Adaletin Örgütsel Bağl1lık Üzerindeki Etkisinde Örgütsel Özdeş- leşmenin Rolü}

Yukarıda araştırmalar ve hipotezleri verilen çalışmalardan da anlaşıldığı gibi örgütsel adalet ve örgütsel bağlılık arasında birçok çalışma yapılmıştır. Ayrıca örgütsel adalet ile örgütsel özdeşleşme arasında da bağımlı ve bağımsız değişken olarak bazı çalışmalar mevcuttur. Bu bilgilere ek olarak örgütsel adalet, örgütsel bağlılık ve örgütsel özdeşleşme arasındaki ilişkilere yönelikte Carmon ve arkadaşları tarafından yapılan bir çalışma mevcuttur. Ancak Carmon ve arkadaşları 2010 yılında yaptıkları bu çalışmada aile ve işletmelerin kaynaştığı organizasyonlarda: çalışanların örgütsel adalet, örgütsel özdeşleşme, örgütsel bağlılık ve türdeşlik (homophily) algılarını incelemişlerdir 
(Carmon ve diğ., 2010, s.210). Fakat Carmon ve arkadaşları tarafından yapılan bu çalışma da örgütsel özdeşleşmenin aracılık rolüne değinilmemiştir. Literatür incelendiğinde örgütsel özdeşleşmenin aracılık rolünün olduğu bazı araştırmacılar tarafından kanıtlanmıştır (Çetinkaya ve Çimenci, 2014; Polat ve Meyda, 2011, s.153; Turunç, 2011, s.143).

Ayrıca örgütsel adalet ve bağlılık arasında yapılan çalışmalarda örgütsel özdeşleşmenin rolü ile ilgili herhangi bir çalışmaya (Science Direct, Google Scholar, JSTOR ) ulaşılamamıştır. Dolaysıyla da yapılan bu çalışma bu eksikliği gidermesi ve aradaki ilişkiyi bulabilmek maksadıyla ortaya konulmuştur. Sonuç olarak tüm hipotezlerin bir arada test edilebilmesi amacıyla aracilık etkisi incelenmelidir. Buradan hareketle de aşağıdaki gibi aracı etkiye yönelik hipotez oluşturulmuştur.

H4: Örgütsel adaletin örgütsel bağlllık üzerindeki etkisinde örgütsel özdeşleşme aracı etkiye sahiptir.

Tüm bu açıklamalar ve bulgulardan hareketle aşağıda araştırmanın temel modeli gösterilmiştir:

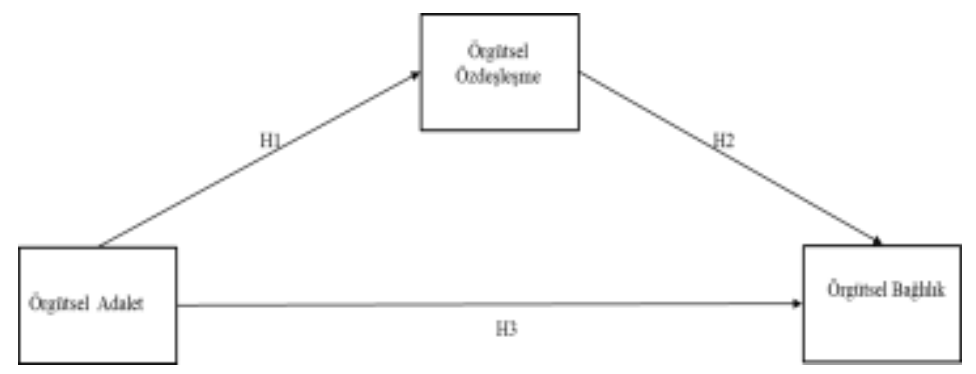

Şekil 1. Araştırmanın modeli

\section{Araştırmanın Metodolojisi}

\section{Araştırmanın Amacı, Örneklemi ve Ölçüm Aracı}

Bu araştırmanın amacı Türkiye'nin doğu ilinde faaliyette olan bir devlet üniversitesinin çalışanlarının iş yerindeki örgütsel adalet düzeylerinin örgütsel 
bağlllık ile ilişkisinin olup olmadığı ve bu etkide örgütsel özdeşleşmenin rolünün nasıl olduğunu ortaya çıarmaktır. Bu kapsamda katılımcılar genel olarak akademik ve idari personelden oluşmaktadır. Ek olarak üniversitenin personel daire başkanından elde edilen verilerden hareketle üniversitede genel olarak 600 kişinin çalıştığı bilinmektedir. Araştırmada veriler tesadüfi örnekleme yöntemi kullanılarak anket aracıllğıyla elde edilmiştir. Ana kütleyi temsilen üniversite çalışanlarına 300 anket dağıtılmış ve toplanmış, bu işlemin sonucunda bazı anketlerde veri kayıpları ve boş cevapların olması nedeniyle herhangi bir sıkıntı barındırmayan ve eksiksiz olarak elimize geçen 206 anket ile çalışma gerçekleştirilmiştir. Ana kütleyi temsilen \%95 güven düzeyi $\% 5$ güven aralığında en az 206 veri girişi sağlanmıştır. Verilerin analizinde ise orijinal SPSS ve AMOS programları uygulanmıştır.

Yapılan bu çalışmanın ölçeklerine bakıldığında çalışanların örgütsel adalet algılarını belirlemeye yönelik 8 madde bulunmaktadır. İşlemsel adalet algısının ölçümünde 2000 yılında Greenberg ve Baran tarafından geliştirilen, dağıtımsal adalet algısının ölçümünde ise 1989 yılında Karambayya ve Brett tarafından geliştirilen ölçekten yararlanılmıştır. Ölçekte bulunan iki madde ise İşcan ve Naktiyok (2004) tarafından oluşturulmuştur. Çalışanların örgütsel bağlılıklarını ölçmek için ise 1991 yılında Meyer ve Allen tarafından geliştirilen ve literatürde yaygın bir şekilde kullanılan, duygusal, normatif ve devamlılık bağl1lı̆̆ 1 ölçekleri ile ölçülmüştür. Örgütsel adalet ve örgütsel bağl1lık ölçekleri dil eşdeğerliliği yapılarak 2004 yılında İşcan ve Naktiyok tarafından kullanılmıştır (İşcan ve Naktiyok, 2004, s.181). Araştırmada kullanılan diğer ölçek ise Örgütsel özdeşleşme ölçeğidir. Bu ölçek ise Van Dick ve arkadaşları tarafından 2004 yılında geliştirilmiştir. Bu ölçek Karabey tarafından dil eşdeğerliliği yapılarak 2005 yılında yüksek lisans tezinde kullanılmıştır. (Karabey ve İşcan, 2007, s.231). Ölçeklerdeki ifadelerin hepsi 5’li Likert tipi şeklindedir.

\section{Bulgular}

Araştırmada öncelikle elde edilen verilerin normal dağılama uygun olup olmadığı incelenmiştir. Bunun içinde Kolmogorov-Smirnov ve Shapiro-Wilk testleri, yaprak testi ve histogram testleri kullanılmıştır. Ayrıca bu analizlerin 
sonucunda veriler $(0,05)$ in altında kalmış dolayısıyla da anlamlı olduğu gözlenmiştir. Buradan hareketle verilerin normal dağılmadığını söylemek mümkündür.

\section{Demografik Bulgular}

Tablo 2. İncelendiğinde üniversitede çalışanlarının \%27.2'i kadın \%72,8'si erkektir. Medeni durumlarına göre ise çalışanların büyük bir çoğunluğu $\% 75,7$ 'si evlidir. Çalışanların gelir durumu yüksek gelirli sayılabilecekleri \%56,8 5001 TL ve üzeri gelire sahiptirler. Üniversite çalışanlarının görev pozisyonlarına bakıldığında çoğunluğunun $\% 57,3$ akademik personelden oluştuğu görülmektedir. Mezuniyet durumlarına göre de yüksek lisans eğitiminin \% 33 ve ilköğretim eğitiminin de $\% 6,3$ oranında olduğu görülmektedir. Son olarak üniversite çalışanlarının yaş durumları incelendiğinde ise 31-35 yaş aralığında \%32 yoğunlaştığı gözlenmiştir. Yani bu üniversitede çalışanların genelinin genç ve orta yaşlarda kişiler olduğu söylenebilir.

Tablo 2. Üniversite çalışanlarının demografik özellikleri

\begin{tabular}{lllccc}
\hline Yaş & Kişi & $\mathbf{( \% )}$ & Mezuniyet & Kişi & $\mathbf{( \% )}$ \\
\hline 25 Yaş ve altı & 10 & 4,9 & İlköğretim & 13 & 6,3 \\
26-30 Yaş & 39 & 18,9 & Lise & 35 & 17,0 \\
31-35 Yaş & 66 & 32,0 & Yüksekokul & 7 & 3,4 \\
36-40 Yaş & 52 & 25,2 & Lisans & 42 & 20,4 \\
41-45 Yaş & 24 & 11,7 & Yükseklisans & 68 & 33,0 \\
46 ve Üzeri & 15 & 7,3 & Doktora & 41 & 19,9 \\
\hline Pozisyon & Kişi & $\mathbf{( \% )}$ & Gelir Düzeyi (Tl) & Kişi & \% \\
\hline Akademik & 118 & 57,3 & 2000 Tl ve altı & 16 & 7,8 \\
İdari & 88 & 42,7 & 2001-3500 Tl & 50 & 24,3 \\
\cline { 1 - 2 } Cinsiyet & Kişi & $\mathbf{\%}$ & 3501-5000 Tl & 23 & 11,2 \\
\cline { 1 - 2 } Kadın & 56 & 27,2 & 5001 Tl ve Üzeri & 117 & 56,8 \\
Erkek & 150 & 72,8 & & & \\
\cline { 1 - 2 } Medeni Durum & Kişi & $\mathbf{( \% )}$ & & & \\
\cline { 1 - 2 } Evli & 156 & 75,7 & & & \\
Bekar & 47 & 22,8 & & & \\
Dul/Boşanmiş & 3 & 1,5 & & & \\
\hline
\end{tabular}




\section{Ölçeklere İlişkin Faktör Analizi Bulguları}

Araştırmada kullanılan her bir ölçeğin faktör yapısını belirlemek için sırasıyla açıklayıcı ve doğrulayıcı faktör analizleri uygulanması gerekmektedir; ancak bu çalışmada uygulanan tüm ölçeklerin Türkiye'de eş değerli olarak kullanımları olduğu için bu kısımda faktör analizlerinden yalnızca doğrulayıcı faktör analizi Amos programı yardımıyla yapılmıştır. Çalışmanın ilk ölçeği olan örgütsel adalet ölçeğinde yer alan 8 ifadeye açıklayıc faktör analizi yapılmış, ölçekteki tüm sorular tek bir boyut altında toplanmış ve bu faktör yüklerinin, 40'ın altında olmaması nedeniyle herhangi bir soru çıkarılmamıştır. Sonuç olarak açıklayıcı faktör analizine ait bulgular Tablo 3'de yer almaktadır. Ayrıca yine bu kısımda ölçeklerin sırasıyla Croanbach Alpha değerleri örgütsel adalet (,901); örgütsel bağlllık (,912) ve örgütsel özdeşleşme (,8999 düzeyinde oldukça güvenilir oldukları söylenebilir (Battal, Durmuş ve Çınar, 2017). Ek olarak DFA analizinde regresyon yüklerinin 0,50 den yüksek olması gerekmektedir (Yaşlıŏlu, 2017).

Bulgulardan hareketle ifadelerin standardize edilmiş regresyon değerlerinin 0,50 'den yüksek olduğu görülmüş ve ölçeğin uyumluluk indeks değerlerini de karşıladığı ancak bazı maddelerin indekslerde gerekli iyileştirmeleri yapmak amaciyla İA3 ile İA2 ve İA1 ile İA4 ve yine İA4 ile DA4 değişkenleri arasında iyileştirmeler uygulanmıştır. Tablo 4 ' de bu değerler gösterilmiştir:

Tablo 4. Örgütsel adalet ölçeğine ilişkin uyum indeksi sonuçlar

\begin{tabular}{llcc}
\hline İndeksler & Referans Değeri & $\begin{array}{c}\text { Modifikasyon Öncesi } \\
\text { Değerler }\end{array}$ & $\begin{array}{c}\text { Modifikasyon Son- } \\
\text { rasi Değerler }\end{array}$ \\
\hline CMIN/DF & $0<\chi 2 / \mathrm{sd} \leq 5$ & 3,452 & 1,825 \\
\hline RMR & $<, 10$ &, 081 &, 063 \\
\hline CFI & $\geq, 90$ &, 894 &, 983 \\
\hline IFI & $\geq, 90$ &, 893 &, 985 \\
\hline TLI & $\geq, 90$ &, 901 &, 972 \\
\hline RMSEA & $<, 05-\leq, 08$ &, 813 &, 063 \\
\hline
\end{tabular}

Araştırmada kullanılan örgütsel adalet ölçeğinin modifikasyon sonrası faktör yükleri aşağıda Şekil 2' de verilmiştir: 


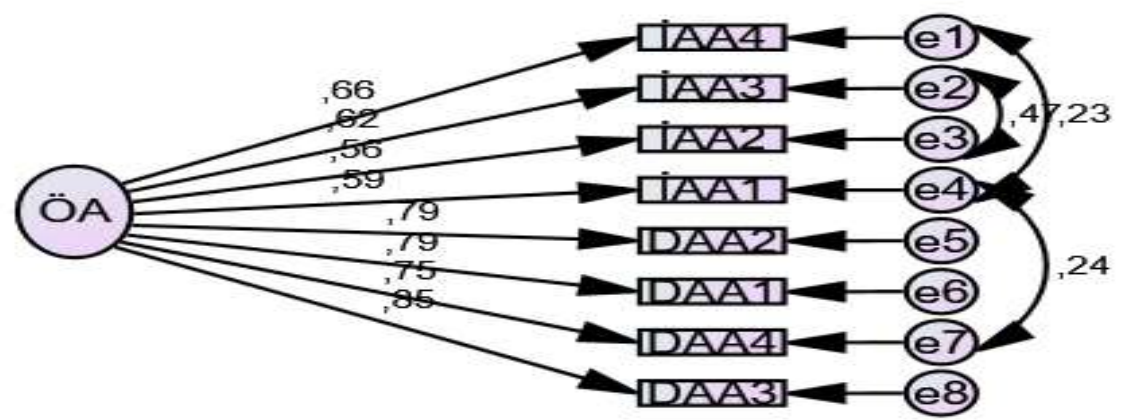

Şekil 2. Örgütsel adalet ölçeğine ilişkin ilişkin doğrulayıcı faktör analizi

Araştırmada kullanılan ikinci ölçek ise 24 ifadeden oluşan örgütsel bağl1lık ölçeğine doğrulayıcı faktör analizi uygulanmıştır. Elde edilen bulgulardan süreklilik bağlılığının 7.ifadesinin regresyon katsayısının 0.50 den düşük olduğu görülmüş ve modelden çıkarılarak doğrulayıcı faktör analizi tekrar uygulanmıştır. Ölçeğin uyumluluk düzeylerine bakıldığında ise yine bazı değerler arasında Amos programı yardımıyla iyileştirmeler yapılmıştır. Öncelikle; DB2 ve DB1 ile NB7 ve NB8 ve DB3 ile NB8 arasında iyileştirmeler uygulanmıştır. Ölçeceğin iyileştirmeler öncesi ve sonrası uyum değerleri Tablo 6'da verilmiştir:

Tablo 5. Örgütsel bağlılık ölçeğine ilişkin uyum indeksi sonuçları

\begin{tabular}{llcc}
\hline İndeksler & Referans Değeri & $\begin{array}{c}\text { Modifikasyon Öncesi } \\
\text { Değerler }\end{array}$ & $\begin{array}{c}\text { Modifikasyon Sonrası } \\
\text { Değerler }\end{array}$ \\
\hline CMIN/DF & $0<\chi 2 / s d \leq 5$ & 5,421 & 2,555 \\
\hline RMR & $<, 10$ &, 109 &, 087 \\
\hline CFI & $\geq, 90$ &, 875 &, 966 \\
\hline IFI & $\geq, 90$ &, 896 &, 969 \\
\hline TLI & $\geq, 90$ &, 887 &, 939 \\
\hline RMSEA & $<, 05-\leq, 08$ &, 892 &, 077 \\
\hline
\end{tabular}

Araştırmada kullanılan örgütsel bağlllık ölçeğinin modifikasyon sonrası faktör yükleri aşağıda Şekil 3'de verilmiştir: 


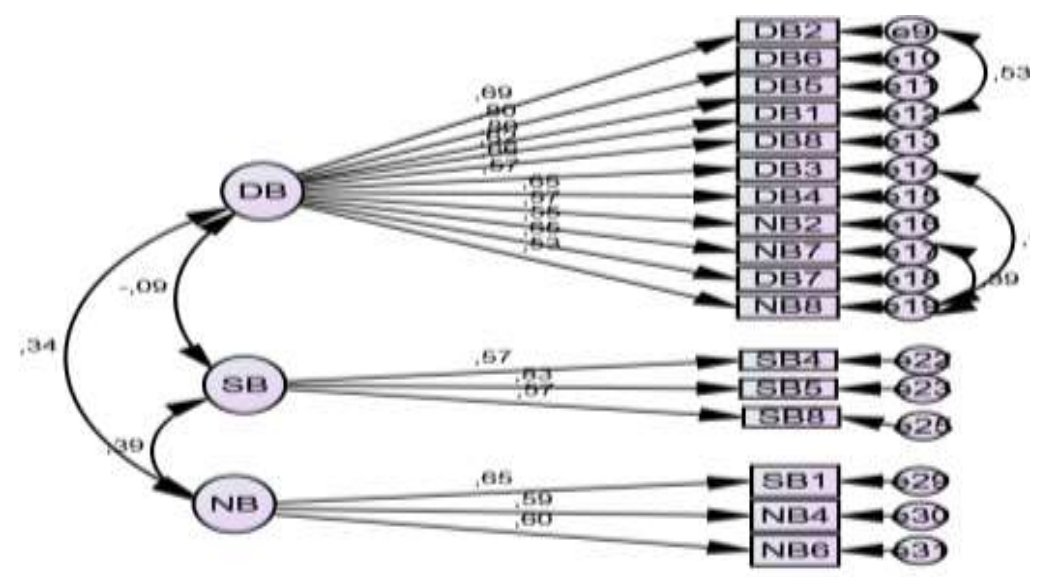

Şekil 3. Örgütsel bağlılık ölçeğine ilişkin doğrulayıcı faktör analizi

Çalışmada kullanılan son ölçek 5 ifadeden oluşan örgütsel özdeşleşme ölçeğine de yine doğrulayıcı faktör analizi uygulanmıştır.

Standardize edilmiş regresyon katsayısının 0,50'den yüksek olması gerekçesiyle Amos programının herhangi bir modifikasyon önerisinin olmadı̆̆ı görülmüştür. Ölçeğe ilişkin doğrulayıcı faktör analizi bulguları Tablo 6'da verilmiştir:

Tablo 6. Örgütsel özdeşleşmeye ilişkin uyum indeksi sonuçlan

\begin{tabular}{ccc}
\hline İndeksler & Referans Değeri & Değerler \\
\hline CMIN/DF & $0<\chi 2 /$ sd $\leq 5$ &, 075 \\
\hline RMR & $<, 10$ &, 005 \\
\hline CFI & $\geq, 90$ & 1,000 \\
\hline IFI & $\geq, 90$ &, 998 \\
\hline TLI & $\geq, 90$ &, 999 \\
\hline RMSEA & $<, 05-\leq, 08$ &, 002 \\
\hline
\end{tabular}

Örgütsel özdeşleşme ölçeğinin faktör yükleri aşağıda Şekil 4'de verilmiştir:

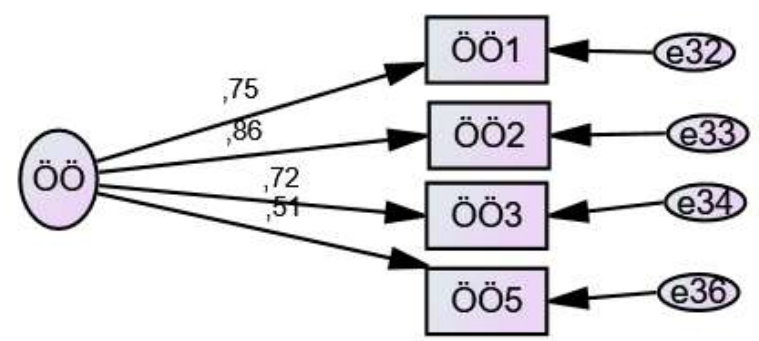

Şekil 4.Örgütsel Özdeşleşmeye İlişkin Doğrulayıcı Faktör Analizi 


\section{Hipotezlerin Testi}

Araştırmada üniversite çalışanlarının, örgütsel adalet, örgütsel bağlllık ve örgütsel özdeşleşme ölçekleri arasındaki ilişkiler korelasyon analizi kullanılarak test edilmiştir. Verilerin normal dağılmadığı daha önceden bilindiği için bu aşamada Spearman korelasyon analizi uygulanmıştır. Böylece bu kavramlar arasındaki ilişkinin şiddetine yönüne bakılmıştır. Elde edilen bulgular Tablo 9'da gösterilmiştir.

Tablo 7. Değişkenler arasındaki korelasyon analizi

\begin{tabular}{|c|c|c|c|c|c|c|c|c|}
\hline & $X$ & SS & 1 & 2 & 3 & 4 & 5 & 6 \\
\hline Örgütsel Adalet & 4,284 & 1,86 & 1 & & & & & \\
\hline Örgütsel Bağlılık & 4,393 & 1,51 &, $368^{* *}$ & 1 & & & & \\
\hline Örgütsel Özdeşleşme & 3,643 & 722 & ,199** & $422^{* *}$ & 1 & & & \\
\hline Duygusal Bağlılık & 3,659 & 697 &, $371^{* *}$ &, $781^{* *}$ & ,396** & 1 & & \\
\hline Süreklilik Bağlılı̆̆ı & 3,168 & 746 & ,077 & ,606** & $141^{*}$ & ,062 & 1 & \\
\hline Normatif Bağ lılığı & 3,089 & 854 &, $250^{* *}$ & , $644^{* *}$ & $295^{* *}$ & $244^{* *}$ & $403^{* *}$ & 1 \\
\hline
\end{tabular}

$p<, 01^{* *} ; p<, 05^{*}$

Tablo 7'ye göre üniversite çalışanlarının genel itibariyle çalıştıkları kuruma karşı güçlü bir şekilde örgütsel bağlılık gösterme eğiliminde oldukları (ort.=4,393) görülmektedir. Ayrıca yine akademik ve idari personelin örgütsel adalet düzeyleri (ort. $=4,284$ ) ile örgütsel özdeşleşme düzeylerinin de (ort.=3,643) yüksek olduğu görülmektedir.

Tablo 7'ye göre çalışanların örgütsel adalet algıları ile örgütsel bağlılık ve örgütsel özdeşleşeme algıları \%99 önem düzeyinde olumlu (pozitif) ve anlamlı yönde ilişkilidir. Ayrıca çalışanların örgütsel bağlılık ve özdeşleşme algıları da \%99 önem düzeyinde olumlu ve anlamlı yönde ilişkilidir. Dolayısıyla çalışanların adalet algıları arttıkça örgütsel bağlılık düzeyleri ile beraber özdeşleşme düzeyleri de pozitif yönde artacaktır. Ayrıca alt boyutlarının ilişkisine bakıldığında ise örgütsel adalet ile süreklilik bağl1lığı arasında anlamlı bir ilişkinin olmadığı görülürken aynı zamanda örgütsel adaletin alt boyutlarından olan duygusal bağlılık ile süreklilik bağlılığı arasında da anlamlı bir ilişki olmadığ 1 görülmüştür. Ancak bu boyutların haricindeki diğer tüm alt boyutlarda \%99 önem düzeyinde olumlu (pozitif) ve anlamlı yönde ilişkilidir. 
Araştırmada değişkenler arasındaki ilişkinin şiddeti ve yönü belirlendikten sonra hipotezler arasındaki ilişkiler incelenmiştir. Öte yandan araştırmada verilerin normal dağılım sergilemediği için YEM modellerinden olan bootstrap yöntemi kullanılmıştır ve böylece yeniden değerlendirmeyi esas alarak direk ve dolaylı etkilerde daha açık bir şekilde ortaya koyulmuştur (Danielsson vd.,2001). Araştırma modelinde örgütsel adalet bağımsız değişken; örgütsel bağlılık ve örgütsel özdeşleşme bağımlı değişken olarak incelenmiştir. Aşağıda genel modele ilişkin sonuçlar Şekil 5 'de verilmiştir:

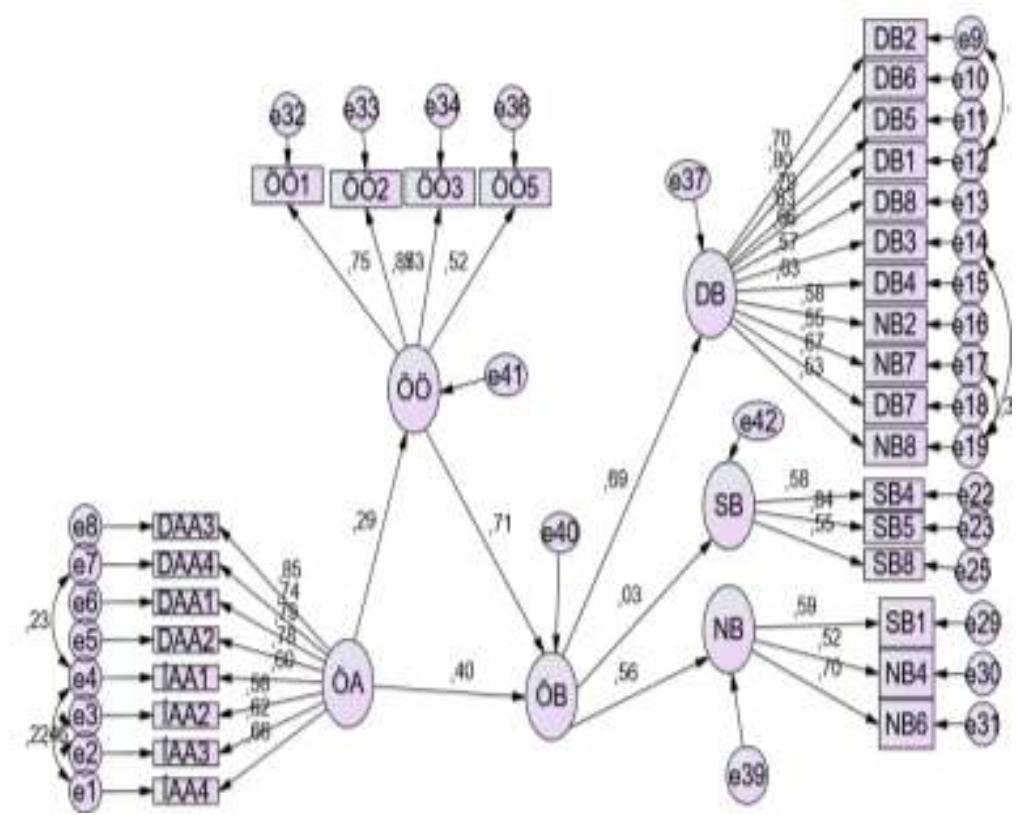

Şekil 5. Standardize edilmiş kestirim sonuçlarının model üzerinde gösterilmesi

Yukarıda verilen genel modelin uyum indeks değerleri Tablo 8'de gösterilmiştir. Tabloya göre genel modelin uyum indeks değerlerini kabul edilebilir düzeylerde sağladığı görülmektedir. Dolayısıyla da bu model istatistiksel olarak yapısal eşitlik modellemesi ile uyum indeksi değerlerine kabul edilebilir sonuçları ortaya çıkarmıştır. 
Tablo 8. Modelin uyum indekslerine ilişkin değer aralıklarn

\begin{tabular}{lcc}
\hline İndeksler & Referans Değeri & Ölçüm Modeli \\
\hline CMIN/DF & $0<\chi 2 / \mathrm{sd} \leq 5$ & 2,024 \\
\hline RMR & $<, 10$ &, 088 \\
\hline CFI & $\geq, 90$ &, 960 \\
\hline IFI & $\geq, 90$ &, 962 \\
\hline TLI & $\geq, 90$ &, 944 \\
\hline RMSEA & $<, 05-\leq, 08$ &, 059
\end{tabular}

Araştırmada geliştirilen hipotezlerin testine ilişkin yapılan YEM analizinde modelin kestirim değerleri Tablo 9'da sunulmuştur.

Tablo 9. Modelin kestirim sonuçları

\begin{tabular}{|c|c|c|c|c|c|c|}
\hline Hipotez & $\begin{array}{l}\text { Yordanan } \\
\text { Değişken }\end{array}$ & $\begin{array}{c}\text { Yordayan } \\
\text { Değişken }\end{array}$ & $\begin{array}{c}\text { Standardize } \\
\text { R. Y. }\end{array}$ & $\begin{array}{r}\text { Alt } \\
\text { Düzey }\end{array}$ & $\begin{array}{r}\text { Üst } \\
\text { Düzey }\end{array}$ & $\mathbf{P}$ \\
\hline H1 & ÖÖ & $<--$ ÖA & ,285 & ,135 & ,426 & , 008 \\
\hline $\mathrm{H}_{2}$ & ÖB & $<--$ ÖÖ & 405 & ,202 & 658 &, 002 \\
\hline $\mathrm{H} 3$ & ÖB & $<--$ ÖA & ,710 & ,503 & ,963 & ,002 \\
\hline
\end{tabular}

Temel model çerçevesinde ortaya koyulan ilişkilerin doğrudan, dolaylı ve toplam etkileri Tablo 10'da sunulmuştur:

Tablo 10. Değişkenlerin doğrudan, dolaylı ve toplam etkileri

\begin{tabular}{llll}
\hline Değişkenler & Etkiler & ÖA & ÖÖ \\
\hline \multirow{2}{*}{ ÖÖ } & Doğrudan &, 285 &, 000 \\
\cline { 2 - 4 } & Dolayli &, 000 &, 000 \\
\cline { 2 - 4 } & Toplam & $\mathbf{2 8 5}$ &, 000 \\
\hline \multirow{2}{*}{ ÖB } & Doğrudan &, 405 &, 000 \\
\cline { 2 - 4 } & Dolayl & $\mathbf{2 0 3}$ &, 000 \\
\cline { 2 - 3 } & Toplam & $\mathbf{6 0 8}$ &, 000 \\
\hline
\end{tabular}

Tablo 9 ve Tablo 10'daki bulgulara bakıldığında çalışanların örgütsel adalet algilarının örgütsel özdeşleşmeyi olumlu $(285)$ ve anlamlı $(, 008)$ olarak etkilediği, bu sebeple de H1'in desteklendiği görülmektedir. Dolaysiyla da üniversitede çalışan akademik ve idari personelin adalete olan inançları arttıkça örgüt ile daha fazla bütünleşecektirler. Tablo 9 ve Tablo 10 'dan elde edilen bir diğer bulgu ise çalışanların adalet algısının, örgütsel bağlılık düzeylerini hem doğrudan olumlu $(405)$ ve anlamlı $(, 002)$ olarak etkilediği hem de örgütsel özdeşleşme yoluyla dolaylı (,203) olarak olumlu ve anlamlı (,002) etkilediğini göstermektedir. Sonuç olarak bulgulara göre çalışanların örgütsel adalet alg1- 
larının örgütsel bağlllık düzeyini doğrudan etkilediği ve bu etkinin de örgütsel özdeşleşmenin modele dâhil edilmesiyle azaldığı görülmüştür. Bu sonuçlardan hareketle de $\mathrm{H} 2$ ve $\mathrm{H} 3$ hipotezleri de kabul edilmiştir.

Araştırmada son olarak çalışanların örgütsel adalet davranışının örgütsel bağlllık üzerindeki etkisinde örgütsel özdeşleşmenin aracı rolünün bulunup bulunmadığını tespit etmek amacıyla örgütsel özdeşleşme aracı değişkeni modelden çıkarılmış ve ede edilen model Şekil $6^{\prime}$ te sunulmuştur:

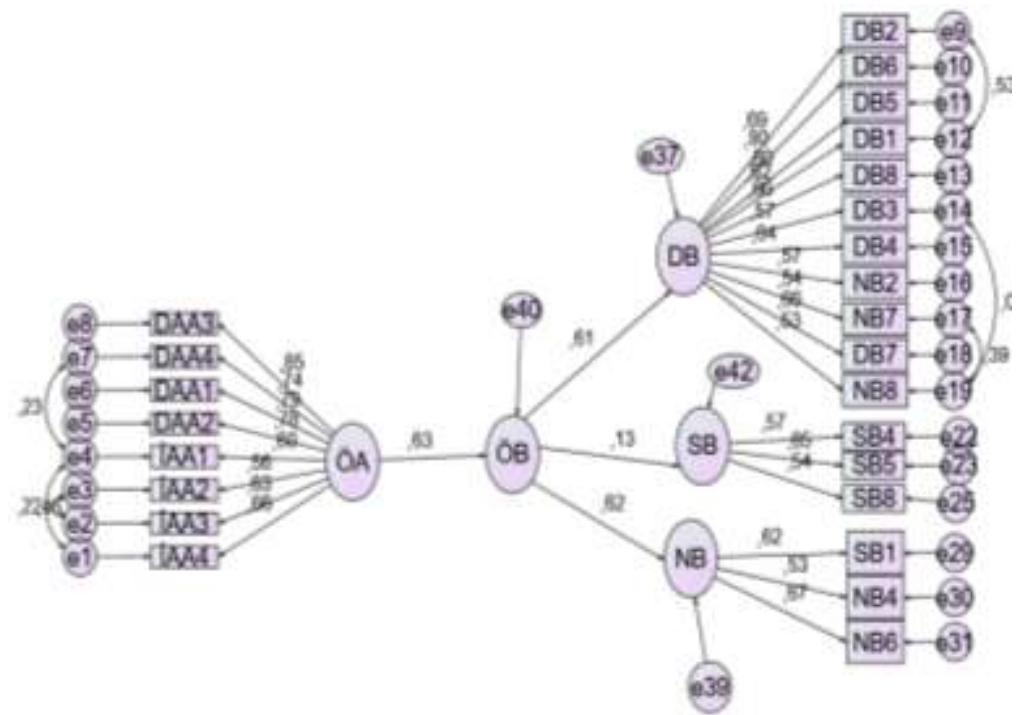

Şekil 6. Aracısız standardize edilmiş kestirim sonuçlarının model üzerinde gösterilmesi

Örgütsel adalet ile örgütsel bağlllık arasındaki ilişkinin doğrudan ortaya koyulduğu aracısız etki Tablo 13' de gösterilmiştir. Bu tabloya göre uyum indeksi değerlerinin yine kabul edilebilir düzeyde olduğu görülmüştür.

Tablo 11. Aracısız modelin uyum indekslerine ilişkin değer aralıkları

\begin{tabular}{lcc}
\hline İndeksler & Referans Değeri & Ölçüm Modeli \\
\hline CMIN/DF & $0<\chi 2 / \mathrm{sd} \leq 5$ & 2,016 \\
\hline RMR & $<, 10$ &, 876 \\
\hline CFI & $\geq, 90$ &, 979 \\
\hline IFI & $\geq, 90$ &, 981 \\
\hline TLI & $\geq, 90$ &, 963 \\
\hline RMSEA & $<, 05-\leq, 08$ &, 060
\end{tabular}


Araştırmada örgütsel adaletin örgütsel bağllılı davranışı üzerindeki etkisinde örgütsel özdeşleşmenin arac rolünü belirlemek için yapılan YEM analizinin kestirim değerleri Tablo 12' de verilmiştir.

Tablo 12. Aracısız modelin kestirim sonuçları

\begin{tabular}{llllll}
\hline $\begin{array}{l}\text { Yordanan } \\
\text { Değişken }\end{array}$ & $\begin{array}{l}\text { Yordayan } \\
\text { Değişken }\end{array}$ & $\begin{array}{l}\text { Standardize } \\
\text { R. Y. }\end{array}$ & $\begin{array}{l}\text { Alt } \\
\text { Düzey }\end{array}$ & $\begin{array}{l}\text { Üst } \\
\text { Düzey }\end{array}$ & P \\
\hline ÖB & $<---O ̈ A$ &, 633 &, 241 &, 880 &, 002 \\
\hline
\end{tabular}

Tablo 12'ye göre örgütsel özdeşleşme modelden çıkarıldığında, çalışanların örgütsel adalet algıları örgütsel bağlılık davranışlarını olumlu yönde $(, 633)$ ve anlamlı (,002) düzeyde etkilemektedir. Tablo 9 ve Tablo 10 'daki aracı değişken olan örgütsel özdeşleşmenin modele dâhil edilmesiyle çalışanların örgütsel adalet algılarının örgütsel bağlılık davranışı üzerindeki etkisinin azaldığı bulgusu dikkate alındığında, çalışanların örgütsel adalet algılarının örgütsel bağlılık davranışı ilişkisinde örgütsel özdeşleşmenin kısmi aracı rol üstlendiği; dolayısıyla H4'ün de desteklendiği görülmektedir.

\section{Tartışma ve Sonuç}

Çalışmanın sonucunda elde edilen korelasyon bulgularına bakıldığında, üniversite çalışanlarının genel itibariyle çalıştıkları kuruma karşı güçlü bir şekilde örgütsel bağlllık gösterme eğiliminde oldukları görülmektedir. Bunun yanında çalışanların, örgütsel adalet düzeylerinin yüksek seviyede olduğu görülürken; aynı zamanda örgütsel özdeşleşme düzeylerinin de orta seviyelerde olduğu görülmüştür. Başka bir ifade ile üniversite çalışanlarının daha çok örgüte bağlılık eğilimi gösterdiği ve adalet beklentilerinin daha yüksek düzeylerde olduğu söylenebilir. Son olarak çalışanların algıladığı örgütsel adalet, bağlılık ve özdeşleşme düzeyleri ile duygusal bağlılıkları arasında olumlu ve anlamlı yönde ilişkiler tespit edilmiştir.

Araştırmada elde edilen diğer bulguda örgütsel adaletin, örgütsel özdeşleşmenin bulunduğu bir modelde örgütsel bağlllığa hem doğrudan etkisinin hem de dolaylı etkisinin bulunduğu yönündedir. Söz konusu bu durumun haricinde aracı değişken olan örgütsel özdeşleşmenin modelden çıkarılarak değerlendirilmesi de yapılmıştır. Böylece aracı değişkenin olmadığı modelde 
örgütsel adaletin örgütsel bağl1lığı olumlu yönde etkilediğini, örgütsel bağlllık algısının da örgütsel adaletteki değişimden zayıf şekilde etkilendiği görülmüştür.

Çalışmada incelenen bir diğer husus ise örgütsel adaletin örgütsel bağlllık üzerindeki doğrudan etkisidir. Buna göre aracı değişkenin dâhil edilmediği durumda bu etkinin yüksek seviyede olduğu belirlenmiştir. Yine bu modelde aracı değişkenin (örgütsel özdeşleşme) bulunmadığı durumda pozitif yönde etkilemesi ve aracı değişkenin modele eklenmesiyle birlikte bu etkinin azalması ve anlamlı olması sonucunda örgütsel adaletin örgütsel bağlılık üzerindeki etkisinde örgütsel özdeşleşmenin kısmi aracı rol üstlendiği görülmüştür. Başka bir ifadeyle örgütsel adalet algisının oluştuğu üniversitelerde dolaylı olarak örgütsel özdeşleşme davranışı gözlenirken; bu durum aynı zamanda örgütsel bağlılık algısının güçlenmesine de sebep olmaktadır.

Bu araştırmanında bazı kapsamları ve sınırlılıkları bulunmaktadır. Örneğin; araştırmanın verilerinin sadece bir ildeki üniversite çalışanları üzerinde yapılmış olması ve yakın bölgelerdeki diğer üniversiteler ile karşılaştırılmamış olması, ayrıca anket tekniği ile alınan cevapların anlık duyguları ve algı durumlarını yansıtması, araştırmanın önemli bazı kısıtları olarak gösterilebilir. İlerde konu ile ilgili yapılması düşünülen araştırmalarda farklı bölgelerdeki üniversiteler ya da farklı ülkelerdeki üniversitelerde karşılaştırmalar yapılarak modelin daha kapsamlı sonuçlar vermesi sağlanabilir.

Ulusal kültüre göre çalışmanın bulgularına bakıldığında daha çok duygusal bağlılık düzeyinin güçlü olduğu görülmüştür. Bu yönüyle bakıldığında Türkiye'nin dişi bir toplum olduğu ve duygularıyla hareket eden bireylerin ağırlıkta olduğu daha önceden yapılan çalışmalarda ortaya koyulmuştur. (Hofstede 1980).Böylece sonuçların ulusal kültür ile uyum içerisinde olduğunu söylemek mümkündür.

Toparlamak gerekirse örgütlerde çalışanların yöneticilerinden ve iş arkadaşlarından destek gördüğünü düşünmesi onları örgüte daha fazla bağlayacaktır. Ayrıca örgüt içinde yöneticiler tarafından sergilenen adalet düzeyi arttıkça çalışanlar kendilerini örgüt ile bütünleşmiş ve özdeş hissedecektir. Bu haliyle çalışanların örgütte herhangi bir sıkıntı durumunda destek alabileceğini hissetmesiyle birlikte yöneticilerin adil davranışlarının görülmesi, çalışanları daha fazla işlerine bağlayacak ve işten ayrılma niyetlerini azaltırken onların gö- 
nüllü çalışma motivasyonlarını olumlu yönde etkileyecektir. Dolayısıyla yöneticiler, insanın en büyük sermaye faktörü olduğunu bilmeli ve yönetim faaliyetlerini sergilerken bu yönde hareket etmelidirler. 


\title{
EXTENDED ABSTRACT
}

\section{The Relationship Between Organizational Justice and Organizational Commitment: The Role of Organizational Identification}

\author{
Fetullah Battal \\ Bayburt University
}

When the literature is analyzed, it is seen that many studies have been done on organizational justice, organizational commitment and organizationalflood identification. For example, when the literature is examined, it is accepted that the high perception of organizational justice of the employees will affect the organizational commitment levels positively (Türköz, Polat and Coşar, 2013, p.285; Bal, 2014, p.75). It is also suggested that the perception of organizational justice has an impact on the perception of organizational identification (Ateş, 2015, p.75; Dwarf, Gü-ney, and Tayfur, 2013, p.1). In addition to these studies, it is possible to find links between organizational commitment and organizational identification in the literature. (Van Knippenberg and Sleebos, 2006, p. 571; Demirel, Derin and Çakınberk, 2011).

However, in this study, it is the first time that whether organizational identification has an intermediary role in the effect of organizational justice perceptions of university employees on organizational commitment perceptions. Therefore, the data obtained as a result of the study can fill an important gap in order to reveal this relationship in our country and can contribute to the literature in this respect. The research was carried out on individuals working in academic and administrative staff at a public university.

Considering the correlation findings obtained as a result of the study, it is seen that university employees tend to show a strong organizational commitment to the institution they work in general. Besides, it is seen that the organizational justice levels of the employees are at a high level; at the same time, organizational identification levels were found to be at medium levels. In other words, it can be said that university employees tend to be loyal to the organization more and their expectations of justice are higher. Finally, positive and meaningful relationships were determined between organizational 
justice, commitment and identification levels perceived by employees and their emotional commitment.

Another finding in the study is that organizational justice has both direct and indirect effects on organizational commitment in a model with organizational identification. Apart from this situation, the organizational identification, which is a mediator variable, was also removed from the model and evaluated. Thus, it was observed that organizational justice had a positive effect on organizational commitment in the model without intermediary variables, and the perception of organizational commitment was weakly affected by the change in organizational justice.

Another issue examined in the study is the direct effect of organizational justice on organizational commitment. Accordingly, it was determined that this effect was at a high level when the mediator variable was not included. Again, in this model, it has been observed that organizational identification plays a partial mediating role in the effect of organizational justice on organizational commitment after the mediator variable (organizational identification) does not affect this positively and after the mediator variable is added to the model. In other words, while the organizational justice perception occurs in universities, indirect organizational identification behavior is observed; this also causes the perception of anger commitment to strengthen.

This research has some scope and limitations. For example; The fact that the data of the research was made only on university employees in one province and was not compared with other universities in the nearby regions, and that the answers received through the survey technique reflect the instantaneous feelings and perception states as some important limitations of the research. In future researches on the subject, it is possible to make comparisons between universities in different regions or universities in different countries to provide more comprehensive results.

Considering the findings of the study according to the national culture, it was seen that the level of emotional commitment was strong. Considering this aspect, Turkey is a society in which the female and the feeling with the weight of the individuals who hare-ket that has been revealed in previous studies. (Hofstede 1980). Thus, it is possible to say that the results are in harmony with the national culture. 
To sum up, the fact that employees in organizations think that they receive support from their managers and colleagues will tie them further to the organization. Also, as the level of justice exhibited by the managers within the organization increases, the employees will feel integrated and identical with the organization.

As the employees feel that they can get support in case of any problem in the organization, seeing the fair behavior of the managers will bind the employees to their more jobs and positively affect their motivation to volunteer while decreasing their intention to leave the job. Therefore, managers should know that human is the biggest capital factor and they should act in this direction while exhibiting their management activities.

\section{Kaynakça / References}

Akram, T., Lei, S., Haider, M. J., Hussain, S. T., ve Puig, L. C. M. (2017). The effect of organizational justice on knowledge sharing: Empirical evidence from the Chinese telecommunications sector. Journal of Innovation \& Knowledge, 2(3), 134-145.

Alexander, S., ve Ruderman, M. (1987). The role of procedural and distributive justice in organizational behavior. Social justice research, 1(2), 177-198.

Allen, N. J., ve Meyer, J. P. (1990). The measurement and antecedents of affective, continuance and normative commitment to the organization. Journal of occupational psychology, 63(1), 1-18.

Allen, N. J., ve Meyer, J. P. (1996). Affective, continuance, and normative commitment to the organization: An examination of construct validity. Journal of vocational behavior, 49(3), 252-276.

Ashforth, B. E., ve Mael, F. (1989). Social identity theory and the organization. Academy of management review, 14(1), 20-39.

Ateş, M. F. (2015). Hizmetkâr liderlik ve örgütsel adaletin örgütsel özdeşleşmeye etkisinde örgütsel güvenin araclık rolü. İşletme Araştırmaları Dergisi, 7(3), 75-95.

Bal, V. (2014). Örgütsel adalet ve örgütsel bağlllık ilişkisi: manisa' daki eğitim kurumlarında bir araştırma. Aksaray Üniversitesi Iktisadi Ve İdari Bilimler Fakültesi Dergisi, 6(1), 1-9.

Battal, F., Durmuş, İ., ve Çınar, E. (2017). The effects of organizational citizenship behaviors and decision-making styles on transformational leadership behavior. Electronic Turkish Studies, 12(31).1-28. 
Becker, T. E. (1992). Foci and bases of commitment: Are they distinctions worth making?. Academy of management Journal, 35(1), 232-244.

Bentler, P.M. (1990). Comparative fit indexes in structural models. Psychol Bull, 107(2), 238-46.

Byrne, Z. S., ve Cropanzano, R. (2001). The history of organizational justice: The founders speak. Justice in the workplace: From theory to practice, 2(1), 3-26.

Carmon, A. F., Miller, A. N., Raile, A. N., ve Roers, M. M. (2010). Fusing family and firm: Employee perceptions of perceived homophily, organizational justice, organizational identification, and organizational commitment in family businesses. Journal of Family Business Strategy, 1(4), 210-223.

Cheney, G. (1982). Identification as process and product: A field study. Unpublished master's thesis, Purdue University, West Lafayette, IN.akt.

Bullis, C., ve Bach, B. W. (1989). Socialization turning points: An examination of change in organizational identification. Western Journal of Communication (includes Communication Reports, 53(3), 273-293.

Cheney, G. (1983). On the various and changing meanings of organizational membership: A field study of organizational identification. Communications Monographs, 50(4), 342-362.

Choudhary, P., ve Kumar, R. (2011). Impact of organizational justice on organizational effectiveness. Industrial Engineering Letters Www. Iiste. Org, 1(3).

Coetzee, M. (2004). The fairness of affirmative action: An organisational justice perspective (Doctoral dissertation, University of Pretoria).

Cohen-Charash, Y., ve Spector, P. E. (2001). The role of justice in organizations: A meta-analysis. Organizational behavior and human decision processes, 86(2), 278-321.

Colquitt, J. A., Conlon, D. E., Wesson, M. J., Porter, C. O., ve Ng, K. Y. (2001). Justice at the millennium: a meta-analytic review of 25 years of organizational justice research. Journal of applied psychology, 86(3), 425.

Colquitt, J. A., Noe, R. A., ve Jackson, C. L. (2002). Justice in teams: Antecedents and consequences of procedural justice climate. Personnel psychology, 55(1), 83-109.

Cropanzano, R., Byrne, Z. S., Bobocel, D. R., ve Rupp, D. E. (2001). Moral virtues, fairness heuristics, social entities, and other denizens of organizational justice. Journal of Vocational Behavior, 58(2), 164-209.

Cüce, H., Güney, S., ve Tayfur, Ö. (2013). Örgütsel adalet algılarının örgütsel özdeşleşme üzerindeki etkisini belirlemeye yönelik bir araştırma. Hacettepe Üniversitesi İktisadi Ve İari Bilimler Fakültesi Dergisi, 31(1), 1-30. 
Çetinkaya, M., ve Çimenci, S. (2014). Örgütsel adalet algısının örgütsel vatandaşlık davranışı üzerindeki etkisi ve örgütsel özdeşleşmenin aracılık rolü: Yapısal eşitlik modeli çalışması. Yönetim Bilimleri Dergisi, 12(23), 237-278.

Danielsson, J., de Haan, L., Peng, L., ve de Vries, C. G. (2001). Using a bootstrap method to choose the sample fraction in tail index estimation. Journal of Multivariate analysis, 76(2), 226-248.

Demirel, E. T., Derin, N., ve Çakınberk, A. (2011). Örgütsel özdeşleşmenin örgütsel bağlılıkla biçimlenmesi: Malatya ve Tunceli özel eğitim kurumları örneği. İşletme Araştırmaları Dergisi, 3(1), 89-121.

Dutton, J. E., J.M. Dukerich ve C.V. Harquail, (1994). Organizational images and member identification. Administrative Science Quarterly, 39(2), 239-263.

Ellemers, N., Spears, R., ve Doosje, B. (1997). Sticking together or falling apart: Ingroup identification as a psychological determinant of group commitment versus individual mobility. Journal of personality and social psycho$\log y, 72(3), 617$.

Folger, R., ve Konovsky, M. A. (1989). Effects of procedural and distributive justice on reactions to pay raise decisions. Academy of Management journal, 32(1), 115-130.

Greenberg, J. (1987). A taxonomy of organizational justice theories. Academy of Management review, 12(1), 9-22.

Greenberg, J. (1990). Employee theft as a reaction to underpayment inequity: The hidden cost of pay cuts. Journal of applied psychology, 75(5), 561.

Greenberg, J. (1990). Organizational justice: Yesterday, today, and tomorrow. Journal of management, 16(2), 399-432.

Griffin, R. W., Bateman, T. S., Cooper, C. L., ve Robertson, I. (1986). Job satisfaction and organizational commitment.

Riketta, M. (2005). Organizational identification: A meta-analysis. Journal of vocational behavior,66(2),358-384.

Hofstede, G. (1980). Culture and organizations. International Studies of Management \& Organization, 10(4), 15-41.

Hollensbe, E. C., Khazanchi, S., ve Masterson, S. S. (2008). How do I assess if my supervisor and organization are fair? Identifying the rules underlying entitybased justice perceptions. Academy of Management Journal, 51(6), 1099-1116.

Hopkins, S. M., ve Weathington, B. L. (2006). The relationships between justice perceptions, trust, and employee attitudes in a downsized organization. The Journal of Psychology, 140(5), 477-498. 
İşcan, Ö. F., ve Naktiyok, A. (2004). Çalışanların örgütsel bağdaşımlarının belirleyicileri olarak örgütsel bağllılı ve örgütsel adalet algıları. Ankara Üniversitesi Siyasal Bilgiler Fakültesi Dergisi, 59(1), 181-201.

Karabey, C. N., ve İşcan, Ö. F. (2007). Örgütsel özdeşleşme, örgütsel imaj ve örgütsel vatandaşlık davranışı ilişkisi: Bir uygulama. Atatürk Üniversitesi İktisadi Ve İdari Bilimler Dergisi, 21(2), 231-241.

Katz, D., ve Kahn, R. L. (1978). The social psychology of organizations (Vol. 2, p. 528). New York: Wiley.

Lambert, E. G., Kelley, T., ve Hogan, N. L. (2013). The association of occupational stressors with different forms of organizational commitment among correctional staff. American Journal of Criminal Justice, 38(3), 480-501.

Lapidot, Y., Kark, R., ve Shamir, B. (2007). The impact of situational vulnerability on the development and erosion of followers' trust in their leader. The leadership quarterly, 18(1), 16-34.

Mael, F., ve Ashforth, B. E. (1992). Alumni and their alma mater: A partial test of the reformulated model of organizational identification. Journal of organizational Behavior, 13(2), 103-123.

Martin, C. L., ve Bennett, N. (1996). The role of justice judgments in explaining the relationship between job satisfaction and organizational commitment. Group \& Organization Management, 21(1), 84-104.

Mathieu, J. E., ve Zajac, D. M. (1990). A review and meta-analysis of the antecedents, correlates, and consequences of organizational commitment. Psychological bulletin, 108(2), 171.

McFarlin, D. B., ve Sweeney, P. D. (1992). Distributive and procedural justice as predictors of satisfaction with personal and organizational outcomes. Academy of management Journal, 35(3), 626-637.

Meyer, J. P., ve Allen, N. J. (1991). A three-component conceptualization of organizational commitment. Human resource management review, 1(1), 61-89.

Meyer, J. P., ve Allen, N. J. (1997). Commitment in the workplace: Theory, research, and application. Sage.

Meyer, J. P., ve Herscovitch, L. (2001). Commitment in the workplace: Toward a general model. Human resource management review, 11(3), 299-326.

Meyer, J. P., Allen, N. J., ve Smith, C. A. (1993). Commitment to organizations and occupations: Extension and test of a three-component conceptualization. Journal of applied psychology, 78(4), 538. 
Moorman, R. H. (1991). Relationship between organizational justice and organizational citizenship behaviors: Do fairness perceptions influence employee citizenship?. Journal of applied psychology, 76(6), 845-855.

Mowday, R. T., Porter, L. W., ve Steers, R. M. (2013). Employee-organization linkages: The psychology of commitment, absenteeism, and turnover. Academic press.

Mowday, R. T., Steers, R. M., ve Porter, L. W. (1979). The measurement of organizational commitment. Journal of vocational behavior, 14(2), 224-247.

Olkkonen, M. E., ve Lipponen, J. (2006).Relationships between organizational justice,identification with organization and work unit, and group-related outcomes.Organizational behavior and human decision processes,100(2),202-215.

Orpen, C. (1994). The effect of organizational commitment on the relationship between procedural and distributive justice,135-136.

Özdemir, A. (2013). Okul yöneticilerindeki adalet ve liyakat ile öğretmenlerdeki sadakat ve gayret arasındaki ilişki. Kuram ve Uygulamada Egitim Yönetimi Dergisi, 19(1), 99-117.

Patrick, H. A. (2012). Commitment of information technology employees in relation to perceived organizational justice. IUP Journal of Organizational Behavior, 11(3), 23-40.

Polat, M., ve Meyda, C. (2011). Örgüt kültürü bağlamında güç eğilimi ve örgütsel bağlılık ilişkisinde örgütsel özdeşleşmenin aracılık rolü. Atatürk Üniversitesi İktisadi ve İdari Bilimler Dergisi, 25(1), 153-170.

Porter, L. W., Steers, R. M., Mowday, R. T., ve Boulian, P. V. (1974). Organizational commitment, job satisfaction, and turnover among psychiatric technicians. Journal of applied psychology, 59(5), 603.

Riketta, M. (2005). Organizational identification: A meta-analysis. Journal of vocational behavior, 66(2), 358-384.

Randeree. K. (2008). Organizational justice: migrant worker perceptions in organizations in the United Arab Emirates. Journal of Business Systems, Governance and Ethics 3 (4), 57-69.

Robbins, S. P., ve Judge, T. A. (2013). Organizational behavior. Pearson education limited.

Riketta, M. (2005). Organizational identification: A meta-analysis. Journal of vocational behavior, 66(2), 358-384.

Spanuth, T., ve Wald, A. (2017). Understanding the antecedents of organizational commitment in the context of temporary organizations: An empirical study. Scandinavian Journal of Management, 33(3), 129-138. 
Sweeney, P. D., ve McFarlin, D. B. (1993). Workers' evaluations of the" ends" and the" means": An examination of four models of distributive and procedural justice. Organizational behavior and human decision processes, 55(1), 23-40.

Tolman, E. C. (1943). Identification and the postwar world. The Journal of Abnormal and Social Psychology, 38(2), 141-148.

Turunç, Ö. (2011). Örgütsel adaletin çalışanların örgütsel özdeşleşme ve işten ayrılma niyetine etkisi: örgütsel özdeşleşmenin aracilık rolü. ISGUC The Journal of Industrial Relations and Human Resources, 13(1), 143-166.

Türköz, T., Polat, M., ve Coşar, S. (2013). Çalışanların örgütsel güven ve sinizm algılarının örgütsel bağlılıkları üzerindeki rolü. Yönetim Ve Ekonomi: Celal Bayar Üniversitesi İktisadi Ve İdari Bilimler Fakültesi Dergisi, 20(2), 285-302.

Tyler, T. R., ve Blader, S. L. (2003). The group engagement model: Procedural justice, social identity, and cooperative behavior. Personality and social psychology review, 7(4), 349-361.

Usmani, S., ve Jamal, S. (2013). Impact of distributive justice, procedural justice, interactional justice, temporal justice, spatial justice on job satisfaction of banking employees. Review of integrative business and economics research, 2(1), 351-369.

Van Knippenberg, D., ve Sleebos, E. (2006). Organizational identification versus organizational commitment: self-definition, social exchange, and job attitudes. Journal of Organizational Behavior: The International Journal Of Industrial, Occupational And Organizational Psychology And Behavior, 27(5), 571-584.

Wu, C. M., ve Chen, T. J. (2018). Collective psychological capital: Linking shared leadership, organizational commitment, and creativity. International Journal of Hospitality Management, 74, 75-84.

Yaşlıoğlu, M. M. (2017). Sosyal bilimlerde faktör analizi ve geçerlilik: Keşfedici ve doğrulayıcı faktör analizlerinin kullanılması. İstanbul Üniversitesi İşletme Fakültesi Dergisi, 46, 74-85.

Yazıcıoğlu, İ., ve Topaloğlu, I. G. (2009). Örgütsel adalet ve bağlılık ilişkisi: Konaklama işletmelerinde bir uygulama, Işsletme Araştırmaları Dergisi 1(1), 3-16.

\section{Kaynakça Bilgisi / Citation Information}

Battal, F. (2020). Örgütsel adalet ve örgütsel bağlılık ilişkisinde örgütsel özdeşleşmenin rolü:Üniversite çalışanları üzerine bir örnek). OPUSUluslararası Toplum Araştırmaları Dergisi, 15(24), 2362-2393. DOI: 10.26466/opus.681809 